\title{
RESPIRATORY HEALTH DISORDERS AMONG WORKERS IN JOINERY WORKSHOPS
}

\author{
By
}

\begin{abstract}
Abdel Rasoul GM, Abu Salem ME, Salem EA, El-Badry AS and Mohamed DN
Department of Public Health and Community Medicine, Faculty of Medicine, Menoufia University

Corresponding author: Mohamed DN.Email:doaa.nasser@med.menofia.edu.eg
\end{abstract}

Submit Date: 2020-09-28

Revise Date: 2020-10-09

Accept Date: 2020-10-13

DOI: 10.21608 /ejom.2020.43849.1212

Authors' contribution: Authors contributed equally to this work.

\begin{abstract}
Introduction: Occupational exposure to wood dust may result in different toxic and al or molds affecting respiratory system and skin. Aim of work: To study the respiratory health disorders among workers in some joinery workshops and to assess their workplace environment. Materials and Methods: A cross sectional study was conducted during the period from the February $1^{\text {st }}, 2019$ to August $31^{\text {th }}, 2020$, on 100 woodworkers chosen from 11 joinery (wood made furniture) workshops, Menouf city, Menoufia governorate. Similar numbers of subjects were chosen randomly from workers' relatives who were never exposed to similar hazards. All participants were interviewed using a predesigned questionnaire. Physical examination and spirometric measurements were performed for them. Environmental study of the workplace was done. Results: The mean concentration of respirable wood dust was $3.61 \pm 2.00 \mathrm{mg} / \mathrm{m}^{3}$, which is higher than the international permissible levels. Workers exposed to wood dust had significantly higher prevalence of respiratory manifestations e.g. rhinitis, cough, expectoration, wheezes, shortness of breathing, chest pain and asthma $(59 \%, 64 \%, 51 \%, 34 \%$, $70 \%, 4 \%$ and $24 \%$; respectively) as well as decreased spirometric measurements compared to the controls. The higher prevalence of respiratory manifestations as well as decreased spirometric measurements were positively correlated with time intensity factor. Conclusion and recommendations: Exposure to wood dust in a concentration more than permissible level has been adversely affecting the respiratory system and causing decrease in spirometric measurements. Regular use of good quality personal
\end{abstract}


protective equipment, proper ventilation and periodic medical examination are highly recommended. Also, regular monitoring of the work environment and keeping dust level below permissible levels are mandatory.

Key words: Wood dust, Joinery workshops, Spirometric measurements and Respiratory manifestations.

\section{Introduction}

The wood furniture industry is one of the most important industries in the world. Egypt is one of the leading countries in this field. In wood furniture industry, there are numerous occupational hazards that might result in different health disorders primarily produced by exposure to dust, noise, chemical substances and ergonomic hazards (Bluff, 2014; Poisson and Chinniah, 2016).

Wood dust is created during all stages of wood processing such as sawing, routing, sanding and other operations. Workers can also be exposed when the dust becomes airborne such as when removing dust from furniture, maintenance activities or when cleaning equipment (e.g. emptying the bag from a dust extraction system or vacuum). Occupational exposure to wood dust may result in different toxic and allergic reactions due to chemicals in the wood itself such as preservative agents including formaldehyde or created by bacteria, fungi or molds (CCOHS, 2017).
Inhaled wood dust causes various respiratory disorders such as allergic rhinitis, chronic bronchitis, asthma, sino-nasal adenocarcinoma and impairment of lung function (Schlünssen et al., 2004). Health disorders that might be due to allergic effects of wood dust on the skin and respiratory systems of man are well documented. It stimulates both cellular and humoral immunity producing manifestation of dermatitis, rhinitis, asthma (OSHA, 2018) or nonallergic effects e.g. chronic exposure to wood dust causes chronic obstructive lung diseases, even in the absence of reported asthma and impaired mucociliary clearance among woodworkers and exposure to saw fumes containing trepans is an adding factor to dust effects (Löfstedt et al., 2017). Inhaled wood dust may cause idiopathic pulmonary fibrosis (Awadalla 2011 and Ricco, 2015).

A variety of external and internal factors influences the severity of developing disorders such as size, shape and 
concentration of dust. Largest particles $(10-20 \mu \mathrm{m})$ are deposited on the walls of the nose and pharynx, while particles at $<5 \mu \mathrm{m}$ size usually impact in smaller airways such as bronchioles and alveoli (Maatta et al., 2006). Type of wood dust produced from hardwood is more dangerous and carcinogenic (Siew et al., 2012). In addition, personal factors as smoking, coexistent chest diseases are also among factors influence the severity of exposure disorders.

\section{Aim of work}

This work aimed to study respiratory health disorders among workers in some joinery workshops and to assess workplace environment.

\section{Materials and Methods}

Study design: It is a cross sectional study.

Place and duration of the study: The study was carried out on randomly chosen 11 joinery workshops at Menouf city (Menoufia Governorate), during the period from February 1 $1^{\text {st }}, 2019$ to August $31^{\text {th }}$, 2020. The industrial processes included in all workshops were sawing, sanding and drilling of unpolished soft and hardwood using hand mechanical equipment. The surface area of each workshop ranged from $\left(50-100 \mathrm{~m}^{2}\right)$. The ventilation of workplace is either natural by windows and fans or artificial by local exhaust ventilation system. The work is of one 8-hour shift/day for six days per week.

\section{Study sample:}

From a total of one hundred thirty three (133) occupationally exposed male workers in the studied workshops, only one hundred (100) workers were recruited in the study after exclusion of non-responders (13 workers) and application of exclusion criteria (20 workers). An unexposed group of one hundred (100) subjects were chosen randomly from workers' relatives who were never exposed to similar hazards. The unexposed group was matched with the exposed one for age, sex and socioeconomic standard.

Inclusion Criteria: workers aged more than 18 years and worked in joinery workshops for more than one year.

Exclusion Criteria: workers with chronic debilitating diseases e.g. Diabetes mellitus (DM), hypertension, heart, liver, renal and chest diseases.

\section{Study methods:}

An interview questionnaire was ap- 
plied at the work place during the work shift. It was done for 8 workers / day and every setting took approximately 30 minutes.

I-All the participants were subjected to a pre-designed questionnaire containing:

a) Personal data: name, age, residence (rural or urban), marital status (single, married and divorced), educational level (illiterate, basic, secondary and high education), special habits (e.g. smoking) and socioeconomic standard. b) Present occupational history (duration of employment, nature of job, hours of the daily work, number of days worked/week, use of protective equipment. c) Past occupational history (place, nature and duration of previous occupations) and additional jobs, present history of respiratory manifestations e.g. rhinitis, cough, expectoration, wheezes, shortness of breath, chest pain and asthma (a chronic disease characterized by recurrent attacks of breathlessness and wheezing, which vary in severity and frequency from person to person (ATS, 2013). d) Family history of diseases running in families e.g. asthma, diabetes mellitus and hypertension. e) Past history relevant to respiratory disorders and systematic diseases as hepatic, renal and heart diseases.

\section{II- Clinical examination:}

General clinical examination including measurement of blood pressure (mmHg),

weight $(\mathrm{kg})$, height $(\mathrm{cm})$, body mass index "BMI= weight $(\mathrm{kg}) /$ height $\left(\mathrm{m}^{2}\right)$ ", pulse

(beat per minute) and body core temperature $\left({ }^{\circ} \mathrm{C}\right)$ followed by local examination of the chest for each participant.

III-Spirometric measurements: were done using the Medical Equipment Europe, PARI Medical Holding GmbH (Starnberg, Germany) Smart Pulmonary Function Test Universal Serial Bus Spirometer to determine forced vital capacity (FVC \%), forced expiratory volume at the first second (FEV1\%), forced expiratory ratio (FEV1/FVC \%), forced expiratory flow during $25-75 \%$ of FVC $\left(\mathrm{FEF}_{25-75} \%\right)$, and peak expiratory flow (PEF \%). The best value of three technically acceptable maneuvers was recorded and expressed as percentages of predicted values. An automatic comment that represented interpretation was obtained. 


\section{IV-Environmental studies:}

Respirable dusts: Air samples were collected from studied workshops at 3 sites: 1- Sawing machines (10 samples), 2- Sanding machines (8 samples), 3- Drilling machines (8 samples). Dust samples were obtained using HETO Personal Dust Sampler, which was loaded with $25 \mathrm{~mm}$ cellulose membrane filters and a sampling pump for respirable dust measurements. The flow rates of portable pumps calibrated at $4 \mathrm{~L} / \mathrm{min}$ and sampling periods were approximately 8 hours/sample. Personal air sampler was fixed on a place so it was as much as possible in the breathing zone of the workers thus the dust collected was representative of his actual exposure. Filters were weighed before and after sampling with digital electrobalence.

\section{Consent}

Written informed consents were signed by all participants before being enrolled into the study.

\section{Ethical approval}

Medical Ethics Committee at Menoufia Faculty of Medicine approved the study protocol before starting.

\section{Data management}

Data were collected, tabulated and statistically analyzed using an IBM personal computer with IBM Statistical Package of Social Science (SPSS) version 22 (SPSS Inc., Chicago, Illinois, USA). Quantitative data normality was tested using Shapiro-Wilk and Kolmogorov-Smirnov tests. Student's t-test was used for parametric data, and the Mann-Whitney test for non- parametric, Chi-squared test $\left(\chi^{2}\right)$ was used to study the association between two qualitative variables, while Fisher's exact test for 2 x 2 tables when expected cell count of more than $25 \%$ of cases was less than 5 . $\mathrm{Z}$ test is a significance test for proportions. Pearson correlation coefficient ( $r$ ) was used to measure the association between two quantitative variables. A $p$ value of $<0.05$ was considered statistically significant. 


\section{Results}

Table (1): Mean \pm SD and Range of concentrations of 8 hour TWA of respirable wood dust $(\mathrm{mg} / \mathrm{m} 3)$ measured in different locations in the studied joinery workshops.

\begin{tabular}{|l||c||c|}
\hline Industrial process & $\begin{array}{c}\text { Number of air samples } \\
\text { No=25 }\end{array}$ & $\begin{array}{c}\text { Dust concentration }\left(\mathbf{m g} / \mathbf{m}^{\mathbf{3}}\right) \\
\text { Mean } \pm \text { SD } \\
\text { Range }\end{array}$ \\
\hline Sawing & 10 & $\begin{array}{c}4.62 \pm 2.13 \\
2.75-8.98\end{array}$ \\
\hline Sanding & 8 & $2.91 \pm 1.36$ \\
& \multirow{2}{*}{8} & $1.01-4.39$ \\
\hline Drilling & 7 & $1.52 \pm 0.88$ \\
& 7 & $0.44-2.86$ \\
\hline
\end{tabular}

Table (1): showed that respirable dust level exceeds the permissible exposure limits stated by NIOSH, $2011\left(1 \mathrm{mg} / \mathrm{m}^{3}\right)$ but lower than the permissible level of the Egyptian Environmental Law 4 Decree 1095, 2011 (5 mg/ m³). 
Table (2): Sociodemographic characteristics of the studied groups:

\begin{tabular}{|c|c|c|c|c|c|c|}
\hline \multirow{2}{*}{$\begin{array}{l}\text { Sociodemographic } \\
\text { characteristics }\end{array}$} & \multicolumn{2}{|c|}{$\begin{array}{l}\text { Exposed } \\
(\mathrm{No}=100)\end{array}$} & \multicolumn{2}{|c|}{$\begin{array}{l}\text { Control } \\
(\mathrm{No}=100)\end{array}$} & \multirow{2}{*}{$\begin{array}{c}\text { Test of } \\
\text { significance }\end{array}$} & \multirow[t]{2}{*}{ p value } \\
\hline & No & $\%$ & No & & & \\
\hline Age (years): (Mean \pm SD) Range & \multicolumn{2}{|c|}{$\begin{array}{l}34.06 \pm 9.41 \\
21-52\end{array}$} & \multicolumn{2}{|c|}{$\begin{array}{c}36.13 \pm 10.36 \\
21-55\end{array}$} & $\mathbf{t}=1.479$ & $>0.05$ \\
\hline $\begin{array}{l}\text { Income: } \\
\text { Enough Not enough }\end{array}$ & $\begin{array}{l}68 \\
32\end{array}$ & $\begin{array}{l}68.0 \\
32.0\end{array}$ & $\begin{array}{l}78 \\
22\end{array}$ & $>0.05$ & $\chi^{2}=2.537$ & $>0.05$ \\
\hline $\begin{array}{l}\text { Education: } \\
\text { Basic } \\
\text { Secondary and above }\end{array}$ & $\begin{array}{l}46 \\
54\end{array}$ & $\begin{array}{l}46.0 \\
54.0\end{array}$ & $\begin{array}{l}38 \\
62\end{array}$ & $>0.05$ & $\chi^{2}=1.314$ & $>0.05$ \\
\hline Residence: Rural Urban & $\begin{array}{c}96 \\
4\end{array}$ & $\begin{array}{l}96.0 \\
4.0\end{array}$ & $\begin{array}{c}94 \\
6\end{array}$ & $>0.05$ & $\chi^{2}=0.421$ & $>0.05$ \\
\hline $\begin{array}{l}\text { Marital status: } \\
\text { Single Married }\end{array}$ & $\begin{array}{l}30 \\
70\end{array}$ & $\begin{array}{l}30.0 \\
70.0\end{array}$ & $\begin{array}{l}20 \\
80\end{array}$ & $>0.05$ & $\chi^{2}=2.661$ & $>0.05$ \\
\hline $\begin{array}{l}\text { Smoking habit: } \\
\text { Smokers Non Smokers }\end{array}$ & $\begin{array}{l}60 \\
40\end{array}$ & $\begin{array}{l}60.0 \\
40.0\end{array}$ & $\begin{array}{l}48 \\
52\end{array}$ & $>0.05$ & $\chi^{2}=2.899$ & $>0.05$ \\
\hline $\begin{array}{l}\text { Smoking index\#: } \\
(\text { Mean } \pm \mathrm{SD})\end{array}$ & $(\mathrm{No}=60$ & $9 \pm 235.8$ & $(\mathrm{No}=48$ & $8.8 \pm 229.5$ & $\mathbf{U}=1437.5$ & $>0.05$ \\
\hline $\begin{array}{ll}\text { Work Duration (years) of expo } \\
\text { Mean: } 15.28 \pm 9.43 \\
\text { Median : } 12 \\
\text { IQR: } \quad 13\end{array}$ & d group & & & & & \\
\hline $\begin{array}{l}\text { Use of protective equipment by } \\
\text { Yes: } \\
\text { NO: }\end{array}$ & posed gy & & & & & \\
\hline $\begin{array}{l}\text { Type of protective equipment } \\
\text { Mask: } \quad 48 \% \\
\text { Earmuffs: } \quad 4 \%\end{array}$ & ed by ex & group: & & & & \\
\hline
\end{tabular}

IQR: Interquartile Range \#: Smoking index=No. of cigarettes per day $x$ smoking duration in years $\mathbf{t}=$ student $\mathrm{t}$-test $\quad \chi^{2}=$ Chi-Squared test $\quad \mathbf{U}=$ Mann-Whitney test 
Table (2): showed a non-significant difference between the exposed and control groups regarding sociodemographic data $(\mathrm{p}>0.05)$, Mean \pm SD duration of work (years) of exposed workers was $15.28 \pm 9.43$, the percent use of protective equipment by exposed group was $42 \%$ and $48 \%$ from them used protective mask.

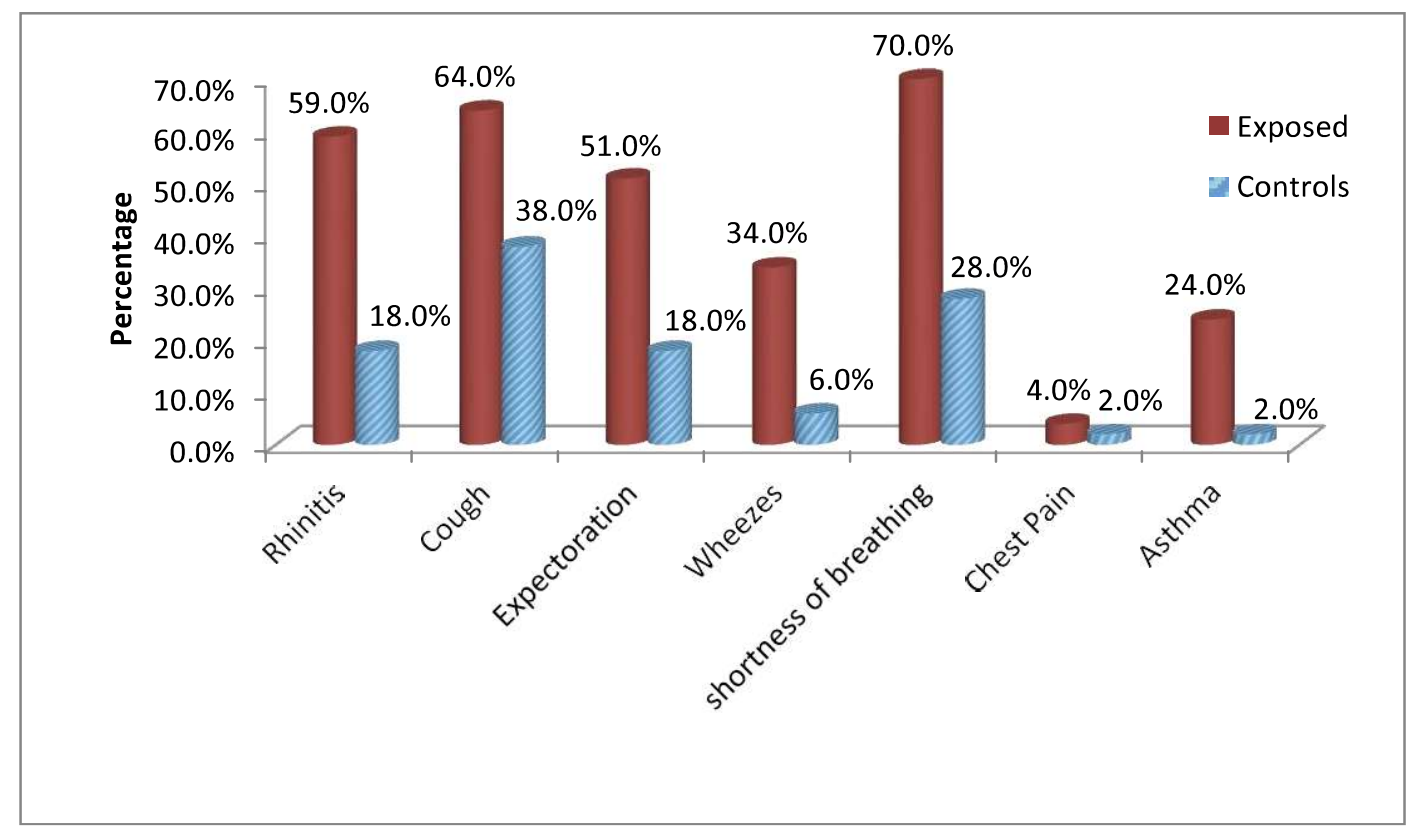

Figure (1): Respiratory manifestations among the studied groups.

Figure (1) showed that respiratory manifestations including rhinitis, cough, expectoration, wheezes, dyspnea and asthma were significantly more prevalent among exposed workers (59.0, 64.0, 51.0, 34.0, 70.0, and $24.0 \%$, respectively) compared to the controls. 
Table (3): Mean \pm SD of spirometric measurements of the studied groups.

\begin{tabular}{|c|c|c|c|c|}
\hline \multirow{2}{*}{ Spirometric measurements } & Exposed $(\mathrm{No}=100)$ & Controls $(\mathrm{No}=100)$ & \multirow[b]{2}{*}{ t-test } & \multirow[b]{2}{*}{$p$ value } \\
\hline & $\operatorname{Mean} \pm$ SD & $\operatorname{Mean} \pm$ SD & & \\
\hline FVC\% & $79.04 \pm 18.68$ & $86.76 \pm 19.91$ & 2.828 & $<0.01 *$ \\
\hline $\operatorname{FEV}_{1} \%$ & $72.73 \pm 13.36$ & $81.89 \pm 15.89$ & 4.413 & $<0.001 * *$ \\
\hline $\mathrm{FEV}_{1} / \mathrm{FVC} \%$ & $81.85 \pm 12.37$ & $86.32 \pm 9.59$ & 2.854 & $<0.01 *$ \\
\hline PEF\% & $69.90 \pm 17.09$ & $75.78 \pm 16.87$ & 2.449 & $<0.01 *$ \\
\hline FEF25-75\% & $81.35 \pm 21.63$ & $84.78 \pm 18.20$ & 1.213 & $>0.05$ \\
\hline
\end{tabular}

*: Significant $\quad * *$ : Highly significant $\quad \mathrm{t}=$ student $\mathrm{t}$-test

Table (3): showed that there were statistically significant lower mean values of $\mathrm{FVC} \%, \mathrm{FEV} 1 \%, \mathrm{FEV} 1 / \mathrm{FVC} \%$, and $\mathrm{PEF} \%$ among the exposed compared to the control group $(\mathrm{P} \varangle 0.05)$.

Table (4) : Pearson correlation between Time Intensity Factor and spirometric measurements of the exposed group $(\mathrm{No}=100)$.

\begin{tabular}{|c|c|c|c|}
\hline \multirow{2}{*}{$\begin{array}{l}\text { Spirometric } \\
\text { measurements }\end{array}$} & \multicolumn{3}{|c|}{ Time Intensity Factor (TIF)\# } \\
\hline & $\mathbf{r}$ & t-test for $r$ & p value \\
\hline FVC\% & -0.135 & 1.349 & $>0.05$ \\
\hline $\mathrm{FEV}_{1} \%$ & -0.100 & 0.995 & $>0.05$ \\
\hline $\mathrm{FEV}_{1} / \mathrm{FVC}_{\mathbf{0}}$ & -0.208 & 2.105 & $<0.05^{*}$ \\
\hline PEF\% & -0.251 & 2.567 & $<0.001 * *$ \\
\hline $\mathrm{FEF}_{25-75} \%$ & -.0 .329 & 3.449 & $<0.05 *$ \\
\hline
\end{tabular}

*: Significant **: Highly significant

\# Time Intensity Factor= Duration of exposure in years $\mathrm{x}$ Concentration of the hazardous substance (a mean 8-hour TWA concentration in milligram)

Table (4) showed a statistically significant negative correlation between time intensity factor and FEV1/FVC\%, PEF\% and FEF25-75\% $(\mathrm{p}<0.05)$. 


\section{Discussion}

Respiratory system effects due to wood dust exposure include decreased lung capacity and allergic reactions in the lungs e.g. hypersensitivity pneumonitis and occupational asthma. Moreover, many hard and softwoods contain chemicals that can irritate the eyes, nose, and throat causing shortness of breath, dryness, and soreness of the throat, sneezing, tearing, and rhinitis (Schlünssen et al. , 2018).

The current study showed that the mean value of respirable wood dust level was $\left(3.61 \pm 2.00 \mathrm{mg} / \mathrm{m}^{3}\right)$ (Table1) which is lower than the permissible level of the Egyptian Environmental Law 4 Decree 1095 (2011) $\left(5 \mathrm{mg} / \mathrm{m}^{3}\right)$ for both hard and soft wood but exceeds the permissible exposure limits stated by NIOSH (2011) $\left(1 \mathrm{mg} / \mathrm{m}^{3}\right)$. This result is consistent with a previous study conducted by Farahat et al. (2010) on Egyptian carpenters where they found that the highest respirable wood dust concentration was generated from sawing operations $\left(5.06 \pm 1.4 \mathrm{mg} / \mathrm{m}^{3}\right)$ and exceeded the permissible exposure limits. Also Neghab et al. (2018) reported a mean value of respirable dust concentration of $(6.76 \pm 1.71 \mathrm{mg} / \mathrm{m} 3)$ in a crosssectional study carried out on 100 male workers exposed to wood dust of 20 randomly selected sawmills in Shiraz, Iran.

In the present study the percent use of protective equipment was $42 \%$. The most frequently used personal protective equipment was dust masks (48\%) ( Table 2). These results were lower than those reported by Adeyemi et al. (2017) who showed that the prevalence of inadequate use of personal protective equipment was $80 \%$ and improper dressing was 74\%. Similarly, Thetkathuek et al. (2016) who studied factors associated with respiratory symptoms among workers in a medium-density fiberboard (MDF) furniture factory in Eastern Thailand found that only $62 \%$ wore masks for dust protection. Thus, the lack of use of protective devices during work contributes to increasing the adverse effects of wood industry on workers' health.

The current study reported a significant higher prevalence of respiratory manifestations e.g. rhinitis, cough, expectoration, wheezes, dyspnea and asthma among exposed compared to controls $(\mathrm{p}<0.05)$ (Figure1). This might be attributed to work hazards recorded in the workshops environment including a high level of respirable wood 
dust with the added effect of poor ventilation and improper use of personal protective equipment. This result was in accordance with many studies in this field as Neghab et al. (2018) who showed that the prevalence of all respiratory manifestations (wheezing, chest tightness, cough, phlegm, and dyspnea) were significantly higher among the exposed workers $(37 \%, 27 \%, 28 \%, 24 \%$, and $74 \%$; respectively) compared to the control group $(11 \%, 13 \%, 3 \%, 6 \%$, and $38 \%$; respectively). Bislimovska et al. (2015) reported a higher prevalence of the respiratory symptoms in the last 12 months in the parquet manufacture workers exposed to hardwood dust as compared to their prevalence in the office workers as a control group with a statistically significant difference for cough and phlegm $(29.7 \%$ and $16.2 \%$; respectively) than the control group (13.5\% and 5.4\%; respectively). Also, Soongkhang and Laohasiriwong (2015) reported that $29.94 \%$ of wood furniture factory workers in the north east of Tailand; had respiratory symptoms including cough, sputum, stuffy nose, breathlessness, and wheezing (18.79\%,15.66\%, 15.07\%, 7.83\%, and $5.09 \%$, respectively). Moreover, Aguwa et al. (2007) in their study on the prevalence of occupational asthma and rhinitis among woodworkers in southeastern Nigeria found that the prevalence of occupational rhinitis was $78 \%$, while that of asthma was $6.5 \%$ among woodworkers.

On comparing exposed workers and controls regarding the spirometric measurements, there were statistically significant lower mean values of $\mathrm{FVC} \%$, FEV1\%, FEV1/FVC\%, and PEF\% among the exposed group compared to the controls $(p<0.05) . \quad F V C \%$ and FEV1\% mean values $(79.04 \pm 18.68$ and72.73 \pm 13.36 ) were lower than the ATS (2013) fifth percentile Lower Limit of Normal (LLN) which was $80 \%$ of predicted for the FVC and FEV1. Other spirometric readings as $\mathrm{FEV} 1 / \mathrm{FVC} \%$, $\mathrm{PEF} \%$ and $\mathrm{FEF}_{25-75} \%$ among the exposed workers were still within the normal values but they were significantly lower than mean values of the controls $(p<0.05)$ (Table 3). These results could be suggested by an increase in the tone of the bronchial muscle, leading to a certain degree of bronchoconstriction related to an irritating effect by exposure to wood dust which limits lung expansion to a normal maximum volume therefore more decrease in spirometric measurements (Hossini et al., 2001; Mohan and Aprajita 2013). Similar results were ob- 
tained by Bislimovska et al. (2015) who reported a significant decrease FEV1\%, $\mathrm{FEV} 1 / \mathrm{FVC} \%$ and $\mathrm{FEF}_{25-75} \%$ among the exposed group $(82.6 \pm 10.2,0,75 \pm 0.05$ and $65.9 \pm 14.1$ respectively) compared to the controls $(86.8 \pm 9.4,0.78 \pm 0.03$ and $70.8 \pm 12.9$; respectively). Also, this result is consistent with Demissie (2019) in his study on the effect of occupational wood dust on pulmonary function among woodworkers in Jimma town, southwest Ethiopia; who showed that mean value of FVC\%, FEV1\%, FEF25$75 \%$ and $\mathrm{PEF} \%$ among woodworkers were $(3.19 \pm 0.64 \mathrm{~L}, 2.70 \pm 0.66 \mathrm{~L}$, $3.97 \pm 1.29 \mathrm{~L} / \mathrm{s}$ and $5.22 \pm 1.63 \mathrm{~L} / \mathrm{s}$; respectively) and among the control group were $(3.69 \pm 0.57 \mathrm{~L}, 3.23 \pm 0.44$ $\mathrm{L}, 4.54 \pm 0.99 \mathrm{~L} / \mathrm{s}$ and $6.01 \pm 1.59 \mathrm{~L} / \mathrm{s}$; respectively) with significant statistical difference between both groups of $(p<0.01)$. On the contrary of these results, Baran et al., (2009) did not find any negative effect of wood dust on ventilatory functions as they used smaller sample size (only 75 workers) and they did not take into consideration dust concentration, particle size and exposure time as affecting variables.

It was known that dust concentration appears to be associated with impairment of respiratory functions, so it was found more valuable to study its combined effect with work duration rather than to study the effect of each factor separately. This is because exposure to low level of concentration for a longer period may cause an effect similar to that of exposure to a high concentration for a short period. Therefore, it was important to calculate what is known as Time Intensity Factor (TIF) that was obtained by multiplication of duration of exposure in years by the concentration of the hazardous substance. So, on application of Pearson correlation between TIF and spirometric measurements of the exposed workers, a significant negative correlation was found between time intensity factor and $\mathrm{FEV} 1 / \mathrm{FVC} \%, \mathrm{PEF} \%$ and $\mathrm{FEF} 25-$ $75 \%(\mathrm{p}<0.05)$ (Table 4). Similar results were obtained by Mbengue et al. (2018) and Demissie (2019) who revealed a negative correlation between spirometric parameters (FVC, FEV1, $\mathrm{FEF}_{25-75} \%$, and PEFR) and duration of work among woodworkers. Also, previous study of Omole et al. (2018) reported that sawmill workers exposed to wood dust in Nigeria more than 10 years had a significant decrease in their FEV1 with a negative correlation between FEV1 and exposure time to wood dust. AbdelRasoul and his co-workers (2017) in a 
study of health disorders among workers in ceramic industry at Queisna City, Menoufia Governorate; clarified the relation of increased TIF and increased prevalence of chest manifestations and decreased spirometric measurements.

\section{Conclusion and recommendations:}

Exposure to wood dust concentration more than permissible level adversely affects the respiratory system and causes decreased spirometric measurements especially with prolonged duration of exposure. Regular use of good quality of personal protective equipment, proper ventilation and periodic medical examination are highly recommended. Also, regular monitoring of the work environment and keeping dust level below permissible levels are mandatory. The current OSHA PEL for respirable wood dust except Western Red Cedar is $5 \mathrm{mg} / \mathrm{m}^{3}$ per cubic meter of air, averaged over an 8-hour shift and Western Red Cedar TWA $2.5 \mathrm{mg} /$ $\mathrm{m}^{3}$ (OSHA, 2018).

\section{Funding}

None

\section{Conflict of interest}

None declared

\section{Acknowledgment}

The authors would like to thank the participants who generously agreed to participate in this work for their time to provide valuable information.

\section{References}

1. Abdel-Rasoul G, Badr S, Allam H, Gabr H and Abdel Monaem A (2017): Respiratory and auditory disorders in a ceramic manufacturing factory (Queisna City, Menoufia Governorate). Menoufia Medical Journal;30(2): 595.

2. Adeyemi $\mathrm{H}$, Olatunji $\mathrm{O}$, Martins $\mathrm{O}$, Akinyemi O, Adama O et al. (2017): Job Safety Assessment of Woodwork Industry in the South-western Nigeria. Arid Zo J Eng Technol Environ; 13(6):817.

3. Aguwa E, Okeke T and Asuza M (2007): The prevalence of occupational asthma and rhinitis among woodworkers in south-eastern Nigeria. Tanzan J Health Res; 9(1):52-5.

4. Awadalla N (2011): Occupational and environmental risk factors of idiopathic pulmonary fibrosis in Egypt. Egypt J Occup Med; 35(1):103-17.

5. ATS "American Thoracic Society" (2013): Official American Thoracic Society Technical Standards: Spirometry in the Occupational Setting. Am J Resp Crit Care; 189(8): 984-94.

6. Baran S, Swietlik K and Teul I (2009): Lung functions: occupational exposure to wood dust. Eur J Med Res; 14 (4): 1-4.

7. Bislimovska D, Petrovska S, and Minov J (2015): Respiratory symptoms and lung function in never-smoking male workers exposed to hardwood dust. Open access Maced J Med Sci; 3(3): 500. Available at https://www. ncbi.nlm.nih.gov/pmc/articles/PMC4877847/.

8. Bluff E (2014): Safety in machinery design and construction: Performance for substantive 
safety outcomes. Saf Sci; 66:27-35.

9.

CCOHS "Canadian Centre for Occupational Health and Safety" (2017): Wood Dust - Health Effects, OSH Answers Fact Sheets. Available at_https://www.ccohs.ca/ oshanswers/chemicals/wood_dust.html.

10. Demissie W (2019): Effect of Occupational Wood Dust on Pulmonary Function among Woodworkers in Jimma Town, Southwest Ethiopia. A Comparative Cross Sectional Study. EC Pulmonol Respir Med; 8:587-93.

11. Egyptian Environmental Law 4 Decree 1095 (2011): Official Gazette No. 199, pages 7781 for noise and 110-2 for dust. Available at https://www.ccohs.ca/oshanswers/chemicals/ wood_dust.html.

12. Farahat $\mathrm{S}$, Ibrahim Yand Abdel-Latif $\mathrm{M}$ (2010): Genotoxicity and oxidative stress due to exposure to wood dust among carpenters. Egypt J Occup Med; 34(1): 83-95.

13. Hossini C, Hossini O, Rahhali A, Verger C, Tripodi D et al. (2001): Respiratory risk in carpenters and cabinet makers. Rev Mal Respir; 18(6 Pt 1):615-22.

14. Löfstedt H, Hagström K, Bryngelsson I-L, Holmström M and Rask-Andersen A (2017): Respiratory symptoms and lung function in relation to wood dust and monoterpene exposure in the wood pellet industry. Ups J Med Sci; 122(2): 78-84.

15. Maattä J, Luukkonen R, Husgafvel-Pursiainen K, Alenius H and Savolainen K (2006): Comparison of hardwood and softwood dust-induced expression of cytokines and chemokines in mouse macrophage RAW 264.7 cells. Toxicology; 218(1):13-21. Available at: https://www.sciencedirect.com/science/article/ abs/pii/S0300483X05004300.

16. Mbengue A, Sow A, Houndjo S, Diaw M, Coly $M$ et al. (2018): Assessment of ventilatory disorders in artisans exposed to wood dust. Natl J Physiol Pharm Pharmacol; 8(12):1641-6.
17. Mohan M and Aprajita N (2013): Effect of wood dust on respiratory health status of carpenters. J Clin diagnostic Res JCDR;7(8):1589.

18. Neghab M, Jabari Z and Shouroki F (2018): Functional disorders of the lung and symptoms of respiratory diseases associated with occupational inhalation exposure to wood dust in Iran; Epidemiol Health: 40, e2018031. Available at https://www.ncbi.nlm.nih.gov/pmc/ articles/PMC6186864/ .

19. NIOSH "National Institute for Occupational Safety and Health" (2011): Health Effects of Exposure to Wood Dust and Wood Dust References. Available at https://www.cdc.gov/ niosh/docs/wooddust/default.html .

20. Omole J, Fabunmi A and Akosile C (2018): Respiratory function of sawmill workers and their relationship to duration of exposure to wood dust seen in Nigeria. J Environ Occup Sci ; 7(1):9-16.

21. OSHA "Occupational Safety and Health Administration" (2018): Wood dust .The Study of Work. US Department of Labor. Available at: https://www.osha.gov/SLTC/etools/ woodworking/health_wooddust.html.

22. Poisson P and Chinniah Y (2016): Managing risks linked to machinery in sawmills by controlling hazardous energies: Theory and practice in eight sawmills. Saf Sci; 84:117-30.

23. Riccò M (2015): Lung fibrosis and exposure to wood dusts: two cases report and review of the literature/zwlóknienie pluc a narazenie na pyl drewna-opisy dwóch przypadków i przeglad literatury. Med Pr; 66(5):739. Available at: http://medpr.imp.lodz.pl/Lung-fibrosis-andexposure-to-wood-dusts-Two-cases-report-andreview-of-the-literature,58311,0,2.html.

24. Schlünssen V, Schaumburg I, Heederik D, Taudorf E and Sigsgaard T (2004): Indices of asthma among atopic and non-atopic woodworkers. Occup Environ Med ; 61(6):50411 
25.

Schlünssen V, Sigsgaard T, RaulfHeimsoth M and Kespohl S (2018): Workplace exposure to wood dust and the prevalence of wood-specific sensitization. Allergol Sel ; 2(1):101.

26. Siew S, Kauppinen T, Kyyrönen P, Heikkilä P and Pukkala E (2012): Occupational exposure to wood dust and formaldehyde and risk of nasal, nasopharyngeal, and lung cancer among Finnish men. Cancer Manag Res; 4:223. Avalaible at: https://www.ncbi.nlm.nih.gov/ pmc/articles/PMC3421471/.
27. Soongkhang I and Laohasiriwong W (2015) Respiratory tract problems among wood furniture manufacturing factory workers in the northeast of Thailand. Kathmandu Univ Med J; 13(2):125-9.

28. Thetkathuek A, Yingratanasuk $\mathrm{T}$ and Ekburanawat W (2016): Respiratory symptoms due to occupational exposure to formaldehyde and MDF dust in a MDF furniture factory in eastern Thailand. Adv Prev Med; 2016. Avalaible at: https://www.ncbi.nlm.nih.gov/ pmc/articles/PMC5227115/. 
